\title{
GCU
}

Glasgow Caledonian

University

University for the Common Good

\section{Brexit, division and individual solidarity: what future for Europe? Evidence from eight European countries}

\author{
Baglioni, Simone; Biosca , Olga; Montgomery, Tom
}

Published in:

American Behavioral Scientist

DOI:

$10.1177 / 0002764219831738$

Publication date:

2019

Document Version

Author accepted manuscript

Link to publication in ResearchOnline

Citation for published version (Harvard):

Baglioni, S, Biosca , O \& Montgomery, T 2019, 'Brexit, division and individual solidarity: what future for Europe? Evidence from eight European countries', American Behavioral Scientist, vol. 63, no. 4, pp. 538-550.

https://doi.org/10.1177/0002764219831738

\section{General rights}

Copyright and moral rights for the publications made accessible in the public portal are retained by the authors and/or other copyright owners and it is a condition of accessing publications that users recognise and abide by the legal requirements associated with these rights.

Take down policy

If you believe that this document breaches copyright please view our takedown policy at https://edshare.gcu.ac.uk/id/eprint/5179 for details of how to contact us. 


\title{
Brexit, division and individual solidarity: what future for Europe? \\ Evidence from eight European countries
}

Simone Baglioni, Olga Biosca, Tom Montgomery (Glasgow Caledonian University)

For the Special Issue of American Behavioral Scientist Guest Edited by Maria Grasso and Christian Lahusen on "European Solidarity at a Crossroads? Altruistic Attitudes and Political Behaviours in Comparative European Perspective”

\section{Corresponding author contact details:}

\author{
Professor Simone Baglioni \\ Yunus Centre for Social Business and Health \\ Glasgow Caledonian University | Cowcaddens Road \\ Glasgow | G4 0BA | Scotland | United Kingdom \\ Email: simone.baglioni@gcu.ac.uk
}




\begin{abstract}
Solidarity amongst member states, one of the European Union's fundamental values, has recently been put to the test by numerous and diverse challenges that have led to a "crisis of solidarity". In the UK, the decision in June 2016 by the electorate to vote to leave the European Union revealed the British dimension of this crisis. However, little is known about the perceptions of other European citizens on this decision, even though it has contributed towards shaping the present and future of the European Union. In this paper, using a representative survey conducted in eight European Countries including the UK, we aim to explore and contrast cross-country evidence on individual perceptions on Brexit. We then aim to establish if an association exists between opinions on Brexit and individual solidaristic attitudes and concrete behaviours of survey respondents. The complex relationship between opinions on this event and expressions of solidarity at different levels (local, national, European and beyond) will be explored using multivariate regression techniques as well as the demographic and socio-economic characteristics of survey respondents.
\end{abstract}

Keywords: Brexit, solidarity, free movement, globalisation 


\section{Short author biographies}

Simone Baglioni is professor of Politics at the Yunus Centre for Social Business and Health, Glasgow Caledonian University. His research focuses primarily on unemployment and labour market issues, social enterprise and social innovation, solidarity and migration. He is currently the coordinator and principal investigator of the Horizon 2020 project Sirius: Skills and Integration of Migrants, Refugees and Asylum Applicants in European Labour Markets (www.sirius-project.eu).

Olga Biosca is a senior lecturer in social business and microfinance at the Yunus Centre for Social Business and Health, Glasgow Caledonian University. Her research focuses primarily on poverty, inequality and social exclusion. She has written articles on social policy and economic development in advanced and developing contexts.

Tom Montgomery is a researcher at the Yunus Centre for Social Business and Health, Glasgow Caledonian University. His research focuses on issues of youth employment, labour market issues, solidarity and social innovation. He is currently focused specifically on issues of labour market integration and the gig economy. 


\section{Introduction}

The decision by the British electorate for their country to leave the European Union has made the 23rd June 2016 an historic day for the EU and its citizens. The resistance of the UK in devolving its authority to supranational European institutions has however for some time led to the relationship between the UK and Europe being characterised as an 'awkward' one (Buller, 1995, 2000; Wilks, 1996; George, 1995, 1998). More broadly, the departure of a keyeconomic, financial and political partner might suggest a failure in the capacity of the EU to maintain the cohesion of its members.

Of course, the decision by the UK to leave the European Union can be understood through the prism of a range of factors. For example, those economic factors that have impacted a section of the population that has experienced labour market fragility and factors that shape the broader European context where fears over immigration have created opportunities for populist and reactionary political forces, movements and parties. Nevertheless, amidst the context of the UK leaving the EU we should also recognise that cohesion among member states was a key ingredient in the new, post-national, federalist polity that the founding fathers of what is today the European Union advocated for in the aftermath of the Second World War (Spinelli and Rossi, [1944] 2006) and underpinned the deepening and widening of the EU-making process (Nugent, 2017). This bi-dimensional path of European Union development, that is its widening borders (expanding the membership to new countries and peoples) and its deepening competences (through overtaking authority on new policy fields) was crucial for the Union's aim to promote solidarity among states as provided for by its founding treaty (cfr. Art. 3 TEU). The vote in favour of Brexit (as the United Kingdom's exit from the EU has been popularly labelled), thus presents a potentially seismic effect on this bidimensional development of transnational solidarity. Nevertheless so far, most of the analyses of the (soon to become abundant) literature on Brexit has neglected solidarity, and has omitted investigation of the motivations for Brexit outside of the UK. Therefore, the insights offered by this paper could not be more relevant for contemporary political analysis and are intended to broaden the scope of the current literature on Brexit by illuminating those factors which catalyse hostility towards the European Union across different European contexts, while shedding light on the status of individual solidaristic attitudes and practices among the peoples that form the European demos.

Although Brexit could be seen to represent a deep wound for the European project, it is surprising that most of the political science literature on Brexit has not shown much interest in discussing Brexit from a comparative perspective across Europe. Neither have scholars developed studies to examine whether the same dynamics that have driven a pro-Brexit decision among UK citizens are to be found among other European citizens/voters. In this paper we shall contribute towards closing this gap by focusing on the perception of Brexit across the European demos, and by discussing the types of attitudes and practices that connect European citizens.

Just as the EU referendum in the UK was characterised by polarisation, our analysis of survey data across eight countries (Denmark, France, Germany, Greece, Italy, Poland, Switzerland, 
and the United Kingdom) confirms a similar degree of polarisation across European countries. Furthermore, our multivariate analysis reveals that the likelihood of a person to vote for Brexit depends on a very similar set of factors scholars have pointed to when seeking explanations for the pro-Brexit vote in the UK (Clarke et al, 2017). Essentially, pro-Brexiters share the same set of socio-demographic and attitudinal characteristics across Europe: they are likely to be citizens with lower levels of education and less stable jobs, they fear immigrants, who are perceived as competitors in the labour market and challengers to their 'established' (group and individual) identity. Therefore, they oppose the EU for its freedom of movement policies that are considered as opening the door to foreigners as intruders.

However, our analysis also considers two additional aspects that were not included in earlier studies: the role that solidarity as altruistic behaviours and values play in the Brexit issue and the role of the economic context in determining the willingness of respondents to support Brexit or to oppose it. Thus, our findings offer a unique and empirically based analysis that builds upon a recognition in recent research that Brexit, although embedded within the idiosyncrasies of the British context, is reflective of a broader phenomenon, one of polarisation that can be identified across a Europe where there is a intensifying opposition between those who have benefitted from globalisation and those who feel it has left them behind (Kriesi et al, 2006, Hobolt, 2016). In fact, we argue that there is a salient segment of society, across a number of member states who perceive the European Union as a threat to their well-being rather than an asset.

The paper unfolds as follows: we first introduce our hypotheses, we then discuss the data and methods, we illustrate the findings, and we then discuss the most salient implications of them. Finally, we present our concluding remarks.

\section{Hypotheses}

Given the watershed nature of the event, Brexit has attracted scholars' attention and a growing literature is emerging that has scrutinized the reasons for the decision by the British people to vote to leave the European Union (Hobolt, 2016; Antonucci et al, 2017; Curtice, 2017; Henderson et al, 2017; Hopkin, 2017; Thompson, 2017; Goodwin et al, 2018). The evidence thus far suggests that pro-Brexit voters have been motivated by a mixture of identity and utilitarian-based fears provoked by the cornerstone no-border policy of the EU. British people felt their identity was being threatened by the increased immigration which was a natural by-product of the free movement of people, one of the 'four freedoms' of the EU single market that sits alongside the freedoms of capital, goods and services. On the other hand, people in the UK felt that increased immigration not only represented a threat for their identity but also for their pocket, as immigrants would compete for their jobs. Hence, the literature points to fear of immigration and more clearly xenophobic attitudes as the most salient predictor of the Brexit vote, along with specific individual features that usually make people more exposed to fear of diversity than others (such as a lower level of education, or insecure employment) (McLaren, 2002; De Vreese and Boomgaarden, 2005; Goodwin and Milazzo, 2017; Vasilopoulou and Wagner, 2017). Furthermore, extant studies have shown 
that those sections of society with a disposition of support towards European integration express a strong sense of attachment towards the European Union as a community and polity.

We assume that similar patterns of perception vis-à-vis immigrants and the European Union will apply across Europe, and therefore we form our first hypothesis (H1) that respondents that will likely opt for Brexit will belong to those social classes that pay the highest costs of globalization (the so called 'losers' from globalization). Therefore those who fear the potential competition emanating from the opening up of countries and markets, usually people with lower educational resources and a precarious employment history, would likely support Brexit. Furthermore, we add the hypothesis (H2) that populations within countries with a poor economic outlook or whose country has suffered from the 2008 economic and financial crisis are more likely to support Brexit as they feel even more exposed to the risk of competition coming from immigrants and the open EU market. This macro-contextual economic uncertainty would increase their own perceived economic fragility. Hence, we shall control for the countries macro-economic outlook and form the further hypothesis (H3) that the weaker the macro-economic outlook, the stronger the likelihood of its citizens to support Brexit. Moreover, we add the hypothesis (H4) that people with a stronger sense of attachment to the EU will likely support the UK to stay in Europe.

Finally, given the saliency that solidarity plays in sustaining the cohesion of the European union, we shall control for it and form the hypothesis (H5) that people that are engaged in any form of solidarity (either with their own country or with a wider focus) will likely be more inclusive and would not fear immigration.

\section{Data and Methodology}

We use data from a nationally representative survey conducted in 2016 for the Horizon 2020 TransSOL (Transnational Solidarity at Times of Crisis) project which was undertaken in eight European countries (Denmark, France, Germany, Greece, Italy, Poland, Switzerland and United Kingdom). The survey, conducted by a survey organization, used demographic and geographical criteria to establish quota sampling methods (age, gender, education level and region). The unemployment rate, expressed as a percentage of the labour force, in 2016 is derived from the Labour market statistics of the Organisation for Economic Cooperation and Development (OECD). The GDP growth as an annual percentage for 2016 is calculated in each country by the World Bank. Table A1 presents the descriptive statistics by country and Table A2 (see Appendix) provides further information on the variables. The final sample has 11865 observations in total.

The dependent variable, Brexit, is derived from responses to the survey question: 'Should the UK remain a member or leave the EU?' It is a binary variable and indicates if the individual supports the withdrawal of the UK from the EU. The independent variables included in the model have been identified in the literature as relevant in shaping attitudes towards EU integration and division (see, for example, Hobolt, 2016 and Clarke et al., 2017). These are: (a) individual sociodemographic characteristics (age, gender, education, being born in the country, employment status, and occupation); (b) Political values and knowledge (left-right self-placement in the political scale, political interest, and political knowledge); (c) Attitudes 
and practices: attachment to the EU, solidarity practices, and attitudes towards immigration. The three solidarity practice variables are binary and indicate if survey participants have supported, in the last 12 months, the rights of other people/groups in their own country, other EU countries or third countries/non-EU countries through various forms of political actions including more contentious as well as more conventional types: attendance at a march, protest or demonstration; donated money; donated time; bought or refused to buy products; passive (paycheck) membership; active membership (volunteering). The attitudes towards immigration were proxied by two variables. Firstly, individual responses to the question: 'Would you mind having immigrant foreign workers as neighbours?' (Yes/No). Secondly, a ten-point bad-good scale on the perceived effect on the economy of the foreigners who had come to live in the country was used. These variables are described in detail in the Table A3 (see Appendix).

We estimate a logistic multilevel random effects model as the individual data have a hierarchical structure; the individuals are nested within eight different countries and, therefore, likely not to be independent within-country (intra-class correlation) due to macroeconomic factors. To further understand the importance of these contextual factors we include the GDP growth rate (model 5) and the national unemployment rate (model 6) as proxy indicators for the impact of the economic crisis in the different European countries (Grasso and Giugni, 2016).

\section{Findings}

We begin the findings' section with descriptive analyses showing how the different countries score regarding the question of whether the UK should leave or remain in the EU, in other words, we consider how countries differ vis-à-vis Brexit. Table 1 shows that 'pro-Brexiters' largely outweigh 'remainers' in Switzerland, France and Greece, while in Poland, Germany, and Denmark the vast majority of respondents would have preferred the UK to stay in the EU. In Italy and in the UK respondents are split in two, with half supporting the UK remaining in the EU and the other supporting the decision to leave. This initial descriptive overview tells us that there are various shades of perception regarding Brexit across the eight countries but which can be identified as three possible clusters: one that is clearly in favour of the idea that the UK should leave the Union, another that is clearly opposed, and a third cluster made by the UK itself and Italy in which people are evenly split between the two scenarios.

Table 1 shows also the percentage of respondents that have a strong or relatively strong attachment to the European Union. We have introduced this aspect because we believe that the perception of Brexit across Europe could also be understood by the sense of belonging that people have towards Europe: in other words, we assumed that people that supported Brexit would likely show a lack of interest or attachment to the European Union in general. In fact, Table 1 reveals a degree of consistency between those countries that host large Brexit-supporting respondents and those who host respondents with a low degree of attachment to Europe, such as Greece and Switzerland. However, the results in Table 1 unveil also an inconsistency with our assumption: France, whose respondents largely favoured 
Brexit, show indeed a strong attachment to Europe (one in every two respondents feels a strong attachment to Europe), and Denmark, where respondents preferred the UK to remain in the EU, reveal a lower level of attachment to the EU.

Such a variety of positions in both the Brexit issue and the attachment to the EU as a political and social community, and the only partial consistency between them, provide some preliminary evidence encouraging our assumption that when looking for possible explanatory paths to Brexit one would need to consider not only individual (micro) variables, but also some context (macro) indicators. In fact, the varied positions in the countries vis-à-vis Brexit suggests that different contexts might lead to different perceptions of Brexit.

In this sense, Table 1 also shows some possible directions for our explanatory analysis to unfold. Firstly, apart from Switzerland (the only non-EU member country in our sample, and where preferences for Brexit could be interpreted as a logical consequence of the decision of that country not to join the EU), the other two countries that are largely pro-Brexit are France and Greece which share some relevant characteristics (along with Italy, where voters are almost equally split in two). In fact, mutatis mutandis, these pro-Brexiter countries and the quasi-Brexiter Italy, have experienced a long-lasting political institutional deadlock provoked by economic stagnation (which, in the case of Greece, has reached a stage of quasibankruptcy status), and, in the case of Greece and Italy, the suffering caused by uncontrollable international events such as the massive influx of refugees escaping Syria which have heavily impacted on the already strained public and private resources of the countries. While countries clearly favouring the UK to remain, that is Poland, Germany, and Denmark, did not experience anything similar to what Greece, France and Italy had to undergo: their economies did not suffer from the economic and financial crisis, hence, they benefited from cohesive societies and political-institutional stability. Therefore, we have developed an explanatory model controlling for macro-economic contextual dimensions.

\section{$\underline{\text { Table } 1}$}

We now move to the findings from our explanatory analyses. To investigate the sociodemographic characteristics, political attitudes and behaviours that determine preferences regarding Brexit, we estimate five different models which are shown in Table A4 (see Appendix). Firstly, we estimate an 'empty' model (model 1), which includes only a random intercept, to observe if a contextual dimension exists. After concluding that the macroeconomic context of the country is relevant, we then include the individual and country-level characteristics. Model 2 includes socio-demographic characteristics and in model 3 we add political values, interest and knowledge. Model 4 presents our results including our main variables of interest which are EU attachment, solidarity practices and attitudes towards immigration. Models 5 and 6 include different country-level variables to account for the economic context.

Our findings are generally in line with the literature that has explored the determinants of individual preferences on Brexit using UK data (Clarke et al, 2017; Goodwin and Heath, 2016). When considering socio-demographic variables, the association between age, having a 
lower level of education, being unemployed and support for Brexit is positive and significant across models (2-6). On the contrary, being female significantly reduces the likelihood of having a preference for Brexit (models 2-6). Other determinants such as being a native of the country and having a manual occupation are, as anticipated, positively and significantly associated to support for Brexit (models 2 and 3) but both factors lose their significance when attachment to the EU, solidarity practices and especially, attitudes towards immigration are introduced into the model specification (models 4-6). In consonance with similar studies on preferences towards integration, individuals that place themselves at the right end of the political spectrum (models 3-6) and are both politically interested and savvy (models 4-6) are more likely to support the withdrawal of the UK from the EU. Similarly to other scholarly studies, individual attachment to the $\mathrm{EU}$ is one of the main factors that shape attitudes towards European integration (Hobolt, 2016). Models 4-6 show that individuals feeling attached to the EU are significantly less likely to support the UK leaving the EU.

The connection between solidarity practices and attitudes towards European integration has not yet been explored in the literature and our results show (models 4-6) that solidarity practices towards disadvantaged groups are only significantly associated with Brexit preferences if these are undertaken within the country. Contrary to expectations, our results suggest that individuals who practice solidarity to support groups in their own country are more likely to support Brexit.

Moreover, echoing the literature (Goodwin and Milazzo, 2017), the role of attitudes towards immigration as key predictors for supporting Brexit in the UK is also confirmed in models 4 , 5, and 6 across the eight European countries in our study. Our findings suggest that support for the UK leaving the EU is particular to a socially distinctive group and seems to be associated with an anti-immigration populist movement across Europe.

Finally, when including the GDP growth rate for 2016 as a country-level variable in model 5, we observe a negative and significant effect of this macroeconomic variable on support for Brexit. This indicates that populations within countries that are in a better economic situation are less likely to support Brexit. Whilst the unemployment rate variable included in model 6 has the positive expected sign, the association is not significant.

\section{Discussion}

When analysing our data what became clear across the different contexts of our study was that a favourable disposition towards voting for Brexit could be mapped on to the issue of immigration. The policy discourses surrounding the immigration in the UK have for some time been shaped by restriction and border control (Statham and Geddes, 2006; Squire, 2008; Mulvey, 2010) and more broadly capitalising on xenophobia and the fear of immigration has been a longstanding tactic of the radical right which in turn has been the subject of extant research for decades (Betz, 1994; Kitschelt and McGann, 1997; Norris, 2005; Semyonov et al, 2006). Therefore, our findings on relating to immigration not only speak to this body of 
work but contribute fresh empirical data and analysis that cuts across the recently reenergised borders of Europe. Our findings indicate that immigration is a significant variable when understanding support from across Europe for the decision taken in the UK to leave the European Union. And solidarity, as action of support for country nationals, is positively correlated with a vote for Brexit. These findings are consistent across the countries of our study and they therefore broaden the scope of existing research into the causes of Brexit and are reflective of those studies conducted in the UK that highlight the importance of immigration in understanding the Brexit vote (Goodwin and Milazzo 2017).

When we turn to the socio-demographic factors that influence support for Brexit, we can see that age, gender and education all have a clear impact on the decision of the UK to leave the European Union. Our findings suggest that age is an important factor and indeed extant research analysing the recent rise in support for right wing populist causes in the USA and Europe has suggested that support for policies, parties and issues that embody xenophobic and/or populist attitudes skew towards the older age range in society (Inglehart and Norris, 2017). In the UK more specifically, recent analysis (Ford and Goodwin, 2017) has indicated that support for Brexit has at least part of its roots in a sentiment within that section of the UK population which rejects the changes that took place in society across the last few decades, resulting in older voters, many of whom are white, nationalist and conservative and who have chosen to articulate their rejection of the more socially liberal society in which they find themselves through a vote to leave the European Union. Therefore, our findings suggest that this generational schism may be apparent across different European contexts and given the right political conditions and opportunities could manifest itself in similar ways.

Another socio-demographic factor that emerges from our findings is gender: across the countries of our study, those who support the decision to leave the European Union are predominantly male. This finding chimes with existing research that suggests support for the authoritarian or populist right trends to be concentrated among male voters (Lubbers et al, 2002). Indeed there is a growing literature which attempts to explain the gender gap in the support for what are populist and xenophobic parties and positions ranging from socioeconomic explanations to explanations focused upon populist attitudes (Immerzeel et al, 2015; Harteveld et al, 2015; Spierings and Zaslove, 2015, 2017).

At the outset of this paper we outlined the broader context which forms the background to our survey, a United Kingdom specifically and a Europe more broadly that have been shaped by the global financial crisis of 2008 and the austerity policies which followed. However this contemporary economic context needs to be grounded in processes that precede the crash of 2008, processes of globalisation (Scholte, 2005) that have transformed the industrial bases of various developed countries, have resulted in a major expansion of the global labour supply (Freeman, 2015) and has created both 'winners' and 'losers' (Kriesi et al, 2006, Essletzbichler et al, 2018). What these conditions have contributed towards in some communities across Europe and beyond is a growing sense of insecurity regarding living standards, a reversal of fortune from the post-war decades of growth and security that many 
had enjoyed and as a consequence what this produces is the type of support for antiimmigration campaigns and xenophobia (Inglehart and Norris, 2017).

In the analysis of our data we indeed found that poorer levels of growth in GDP were a contributing factor to increased levels of support for leaving the European Union, with those in favour of Brexit located within countries with the most sluggish growth. Moreover, in the course of our analysis we observed that the findings from Greece were at the forefront of this support and thus chime with and also contribute to existing research that has scrutinised the impact of the Eurozone crisis on the growth of Euroscepticism in Greece (Clements et al, 2014). Furthermore, our findings offer a comparative and empirical substantiation of the view that support for leaving the European Union is correlated with lower levels of education - i.e. those who are more vulnerable in labour markets (Hobolt, 2016). These findings also resonate with existing research focused upon the UK which has revealed that support for Brexit was concentrated in geographies and sections of society with high levels of poverty and low levels of skills.

\section{Conclusion}

Although the UK could often be regarded as 'reluctant Europeans' (Gowland and Turner, 2014), the decision by a majority of British voters to leave the EU marks the end to a long period of European integration. Such a relationship, initially binding the UK to eight other countries, had expanded over five decades to include 27 other states and hundreds of millions of people. The European Community, as it was known for many years, progressed by means of widening its geo-spatial scope and by a deepening its authority, incrementally increasing its decision-making power to the detriment of national governments. All of this stemmed from the idea that Europe would benefit from countries pooling their resources and facing common risks, and that the European demos would support such a project by developing solidarities that span across national boundaries.

What the Brexit vote, along with the electoral success of anti-European parties across Europe, tell us about the European project is that the development of the transnational solidarity necessary to entrench and accelerate political and economic infra-state solidarity remains, after many decades, a largely unlocked potential. This potential has been jeopardized by globalization and by the 2008 global financial crisis and its consequences including the approach of the EU in addressing the challenges it presented. Moreover, European solidarity has been undermined by the reluctance of European leaders to progress towards a more integrated Europe.

Our survey of citizens' positions concerning Brexit across eight countries has revealed that there are large sections of the European population that are ready to be lured by the arguments deployed in the Leave campaign in the UK (in some countries, including an EU founding state France, this section of the population outnumbers those who oppose Brexit) and that pro-Brexit individuals are more likely to be found among those who fear Europe for its open-border policies, and consider immigrants as a threat to their economic stability and to 
the integrity of their identity. Paradoxically, what is, for many, the greatest asset of the European Union, the free movement of people and transnational connections and collaborations, appears to represent to many people its most dangerous and 'dark side'. That among this latter section of populations are those with fewer educational resources and more fragile economic positions in the labour market, or those who live in countries suffering from economic stagnation, should perhaps sound as a warning to those who believe in the value of the EU as reflective of a social-democratic model of society. 
Table 1. Percentages of respondents supporting Brexit; percentages of respondents expressing strong attachment to the EU

\begin{tabular}{lccccccccc}
\hline & Denmark & France & Germany & $\begin{array}{c}\text { Greec } \\
\mathrm{e}\end{array}$ & Italy & Poland & $\begin{array}{c}\text { Switzerlan } \\
\mathrm{d}\end{array}$ & $\begin{array}{c}\text { United } \\
\text { Kingdom }\end{array}$ & $\begin{array}{c}\text { All } \\
\text { \% of respondents supporting }\end{array}$ \\
$\begin{array}{l}\text { Brexit } \\
\text { \% of respondents with strong }\end{array}$ & 41.7 & 60.1 & 41.4 & 59.1 & 50.6 & 24.3 & 67.4 & 50.6 & 49.5 \\
$\begin{array}{l}\text { attachment to the EU } \\
\mathrm{N}\end{array}$ & 41.9 & 53.9 & 57.6 & 37.6 & 53.1 & 73.7 & 29.4 & 45.3 & 48.7 \\
\hline
\end{tabular}




\section{References}

Antonucci, L., Horvath, L., Kutiyski, Y., \& Krouwel, A. (2017). The malaise of the squeezed middle: Challenging the narrative of the 'left behind' Brexiter. Competition \& Change, 21(3), 211-229.

Betz, H. G. (1994). Radical right-wing populism in Western Europe. Springer.

Buller, J. (1995) 'Britain as an Awkward Partner: Reassessing Britain's relationship with the EU', Politics, 15 (1), pp.33-42

Buller, J. (2000). National Statecraft and European Integration. A\&C Black.

Clarke, H. D., Goodwin, M., \& Whiteley, P. (2017). Why Britain voted for Brexit: an individual-level analysis of the 2016 referendum vote. Parliamentary Affairs, 70(3), 439-464.

Clements, B., Nanou, K., \& Verney, S. (2014). 'We no longer love you, but we don't want to leave you': the Eurozone crisis and popular Euroscepticism in Greece. Journal of European Integration, 36(3), 247-265.

Cowburn, A. (2016) Nigel Farage refuses to apologise for 'Breaking Point' poster in final pitch to voters. The Independent, $22^{\text {nd }}$ June 2016.

Cummings, D. (2017) How the Brexit referendum was won, The Spectator, $9^{\text {th }}$ January 2017. https://blogs.spectator.co.uk/2017/01/dominic-cummings-brexit-referendum-won/

Curtice, J. (2017). Why Leave won the UK's EU referendum. JCMS: Journal of Common Market Studies, 55(S1), 19-37.

De Vreese, C. H., \& Boomgaarden, H. G. (2005). Projecting EU referendums: Fear of immigration and support for European integration. European Union Politics, 6(1), 59-82.

Essletzbichler, J., Disslbacher, F., \& Moser, M. (2018). The victims of neoliberal globalisation and the rise of the populist vote: a comparative analysis of three recent electoral decisions. Cambridge Journal of Regions, Economy and Society, 11(1), 73-94.

European Council (2016) Statement of the EU Heads of State or Government, 18/03/2016. European Council, Brussels. Available from http://www.consilium.europa.eu/en/press/pressreleases/2016/03/18/eu-turkey-statement/

Ford, R., \& Goodwin, M. (2017). A nation divided. Journal of Democracy, 28(1), 17-30.

Freeman, R. (2005). What really ails Europe (and America): The doubling of the global workforce. The Globalist, 3, 2005.

George, S. (1995). A reply to Buller. Politics, 15(1), 43-47.

George, S. (1998). An awkward partner: Britain in the European Community. Oxford University Press, USA. 
Goodwin, M., \& Milazzo, C. (2017). Taking back control? Investigating the role of immigration in the 2016 vote for Brexit. The British Journal of Politics and International Relations, 19(3), 450-464.

Goodwin, M., Hix, S., \& Pickup, M. (2018). For and against Brexit: a survey experiment of the impact of campaign effects on public attitudes toward EU membership. British Journal of Political Science, 1-15.

Gowland, D., \& Turner, A. (2014). Reluctant Europeans: Britain and European Integration 1945-1998. Routledge.

Giugni, M., \& Grasso, M. (2016). Austerity and protest: Popular contention in times of economic crisis. Routledge.

Harteveld, E., Van Der Brug, W., Dahlberg, S., \& Kokkonen, A. (2015). The gender gap in populist radical-right voting: examining the demand side in Western and Eastern Europe. Patterns of Prejudice, 49(1-2), 103-134.

Henderson, A., Jeffery, C., Wincott, D., \& Wyn Jones, R. (2017). How Brexit was made in England. The British Journal of Politics and International Relations, 19(4), 631-646.

Hobolt, S. B. (2016). The Brexit vote: a divided nation, a divided continent. Journal of European Public Policy, 23(9), 1259-1277.

Hopkin, J (2017) Brexit, cartel politics and the neoliberal consensus: Party, politics and voter disaffection in the UK. The British Journal of Politics and International Relations, 19(3): 466-479

Immerzeel, Tim, Hilde Coffé, and Tanja van der Lippe (2015). 'Explaining the Gender Gap in Radical Right Voting: A Cross-National Investigation in 12 Western European Countries', Comparative European Politics, 13:2, 263-286.

Inglehart, R., \& Norris, P. (2017). Trump and the populist authoritarian parties: the silent revolution in reverse. Perspectives on Politics, 15(2), 443-454.

Kitschelt, H., \& McGann, A. J. (1997). The radical right in Western Europe: A comparative analysis. University of Michigan Press.

Kriesi, H., Grande, E., Lachat, R., Dolezal, M., Bornshier, S. \& Frey, T. (2006) Globalization and the transformation of the national political space: six European countries compared, European Journal of Political Research 45: 921-956.

Lubbers, M., Gijsberts, M., \& Scheepers, P. (2002). Extreme right- wing voting in Western Europe. European Journal of Political Research, 41(3), 345-378.

McLaren, L. M. (2002). Public support for the European Union: cost/benefit analysis or perceived cultural threat?. The Journal of Politics, 64(2), 551-566. 
Mulvey, G. (2010). When policy creates politics: The problematizing of immigration and the consequences for refugee integration in the UK. Journal of Refugee Studies, 23(4), 437-462.

Norris, P. (2005). Radical right: Voters and parties in the electoral market. Cambridge University Press.

Nugent, N. (2017). The government and politics of the European Union. Palgrave.

OECD (2018), Unemployment rate (indicator). doi: 10.1787/997c8750-en (Accessed on 10 April 2018)

Schmidt, V. A. (2017). Britain-out and Trump-in: a discursive institutionalist analysis of the British referendum on the EU and the US presidential election. Review of International Political Economy, 24(2), 248-269.

Scholte, J. A. (2005). Globalization: A critical introduction. Palgrave Macmillan.

Semyonov, M., Raijman, R., \& Gorodzeisky, A. (2006). The rise of anti-foreigner sentiment in European societies, 1988-2000. American sociological review, 71(3), 426-449.

Spinelli, E. \& Rossi. E. [1944] (2006). Il manifesto di Ventotene, Milan: Mondadori.

Statham, P., \& Geddes, A. (2006). Elites and the 'organised public': Who drives British immigration politics and in which direction?. West European Politics, 29(2), 248-269.

Spierings, N., \& Zaslove, A. (2015). Gendering the vote for populist radical-right parties. Patterns of Prejudice, 49(1-2), 135-162

Spierings, N., \& Zaslove, A. (2017). Gender, populist attitudes, and voting: explaining the gender gap in voting for populist radical right and populist radical left parties. West European Politics, 40(4), 821-847.

Squire, V. (2008). Accounting for the dominance of control: Inter-party dynamics and restrictive asylum policy in contemporary Britain. British Politics, 3(2), 241-261.

Thompson, H. (2017). It's still the 2008 crash. The Political Quarterly, 88(3), 391-394.

Urquijo-Sanchez, I. \& Black, J. (2017). Europe and the Mediterranean. Fatal Journeys, vol. 3, p.99. International Organization for Migration (IOM), Geneva.

Vasilopoulou, S., \& Wagner, M. (2017). Fear, anger and enthusiasm about the European Union: Effects of emotional reactions on public preferences towards European integration. European Union Politics, 18(3), 382-405.

Wilks, S. (1996) Britain and Europe: An Awkward Partner or an Awkward State? Politics, Vol 16, Issue 3, pp.159-165.

Wilson, G. K. (2017). Brexit, Trump and the special relationship. The British Journal of Politics and International Relations, 19(3), 543-557. 
Appendix

Table A1. Descriptive statistics

\begin{tabular}{|c|c|c|c|c|c|}
\hline Variable & Obs & Mean & Std. Dev. & Min & Max \\
\hline Brexit supporter & 11865 & 0.495 & 0.500 & 0 & 1 \\
\hline Age & 11865 & 48.900 & 15.966 & 18 & 96 \\
\hline Female & 11865 & 0.461 & 0.498 & 0 & 1 \\
\hline Education level (lower education) & 11865 & 0.312 & 0.463 & 0 & 1 \\
\hline Unemployed & 11865 & 0.088 & 0.283 & 0 & 1 \\
\hline Born in UK & 11865 & 0.927 & 0.259 & 0 & 1 \\
\hline Manual & 11865 & 0.180 & 0.384 & 0 & 1 \\
\hline Attachment towards EU & 11865 & 0.487 & 0.500 & 0 & 1 \\
\hline Support rights inside UK & 11865 & 0.564 & 0.496 & 0 & 1 \\
\hline Support rights in EU & 11865 & 0.326 & 0.469 & 0 & 1 \\
\hline Support rights outside EU & 11865 & 0.391 & 0.488 & 0 & 1 \\
\hline & 11865 & 4.987 & 2.845 & 0 & 10 \\
\hline $\begin{array}{l}\text { Would mind having immigrants/ } \\
\text { foreign workers as neighbours }\end{array}$ & 11865 & 0.312 & 0.463 & 0 & 1 \\
\hline Left-right scale $(0-10)$ & 11865 & 5.138 & 2.601 & 0 & 10 \\
\hline
\end{tabular}




$\begin{array}{llllrr}\text { Political knowledge } & 11865 & 0.532 & 0.499 & 0 & 1 \\ \text { Political interest } & 11865 & 0.747 & 0.435 & 0 & 1 \\ \text { Unemployment rate (\%) } & 11865 & 8.821 & 6.067 & 4.1 & 23.5 \\ \text { GDP growth (\%) } & 11865 & 1.487 & 0.842 & -0.2 & 2.9\end{array}$

Table A2: Variable distributions by country

\begin{tabular}{|c|c|c|c|c|c|c|c|c|c|}
\hline & Denmark & France & Germany & Greece & Italy & Poland & Switzerland & UK & All \\
\hline Brexit supporter (\%) & 41.7 & 60.1 & 41.4 & 59.1 & 50.6 & 24.3 & 67.4 & 50.6 & 49.5 \\
\hline Age & 50.5 & 49.3 & 49.0 & 49.0 & 49.4 & 47.2 & 47.7 & 49.1 & 48.9 \\
\hline Female & 42.9 & 45.4 & 46.9 & 46.9 & 48.0 & 47.8 & 45.3 & 45.3 & 46.1 \\
\hline Education level (Lower education) & 27.8 & 32.1 & 21.5 & 42.7 & 48.3 & 20.6 & 24.7 & 33.1 & 31.2 \\
\hline Unemployed & 7.0 & 5.4 & 3.3 & 24.4 & 11.8 & 8.6 & 6.9 & 3.7 & 8.8 \\
\hline Born in country & 94.7 & 95.8 & 92.6 & 92.5 & 96.9 & 99.3 & 81.6 & 90.3 & 92.7 \\
\hline Manual & 26.7 & 16.0 & 13.6 & 13.4 & 15.8 & 23.7 & 15.1 & 20.5 & 18.0 \\
\hline Left-right scale & 5.1 & 5.3 & 4.7 & 5.2 & 5.0 & 5.1 & 5.5 & 5.3 & 5.1 \\
\hline Political knowledge & 42.3 & 41.7 & 65.2 & 86.1 & 56.0 & 31.3 & 53.3 & 46.2 & 53.2 \\
\hline Political interest & 76.3 & 70.3 & 82.8 & 65.0 & 71.2 & 82.8 & 71.1 & 77.6 & 74.7 \\
\hline Attachment towards EU & 41.9 & 53.9 & 57.6 & 37.6 & 53.1 & 73.7 & 29.4 & 45.3 & 48.7 \\
\hline Support rights inside UK & 52.4 & 52.9 & 54.0 & 65.2 & 52.3 & 67.6 & 63.5 & 43.6 & 56.4 \\
\hline Support rights in EU & 26.7 & 28.6 & 33.2 & 37.1 & 36.6 & 40.1 & 36.5 & 21.8 & 32.6 \\
\hline Support rights outside EU & 39.9 & 34.4 & 42.9 & 36.4 & 37.1 & 43.4 & 48.3 & 29.6 & 39.1 \\
\hline Bad-good effect of foreigners in the economy & 5.35 & 4.5 & 5.9 & 3.6 & 4.7 & 4.2 & 5.8 & 5.6 & 5.0 \\
\hline Would mind having immigrants/ foreign workers as neighbours & 24.5 & 39.6 & 23.9 & 35.5 & 35.2 & 34.6 & 24.1 & 34.7 & 31.2 \\
\hline Unemployment rate 2016 & 6.2 & 10.1 & 4.1 & 23.5 & 11.7 & 6.2 & 4.9 & 4.8 & 8.8 \\
\hline
\end{tabular}


Notes: All means are reported in percentages with the exception of age, scale of effect of foreigners in the economy of the host country and left-right political scale.

\section{Table A3: Variables}

\begin{tabular}{|c|c|c|}
\hline Variable & Survey question & Coding \\
\hline Brexit supporter & Should the UK remain a member or leave the EU? & $\begin{array}{l}1=\mathrm{UK} \text { should leave the EU } \\
0=\text { Remain a member of EU }\end{array}$ \\
\hline Age & How old are you? & Measured in years \\
\hline Female & Are you male or female? & $\begin{array}{l}1=\text { Female } \\
0=\text { Male }\end{array}$ \\
\hline Education level (lower education) & Highest education level & $\begin{array}{l}1=\text { Lower education } \\
0=\text { Intermediate } / \text { higher education }\end{array}$ \\
\hline Unemployed & What you have been doing for the past 7 days? & $\begin{array}{l}1=\text { Unemployed } \\
0=\text { Employed, in education, permanently sick, } \\
\text { retired, housework, military service }\end{array}$ \\
\hline Born in country & Were you born in *country*? & $\begin{array}{l}1=\text { Yes } \\
0=\mathrm{No}\end{array}$ \\
\hline Manual occupation & Which option best describes the sort of paid work you do? & $\begin{array}{l}\text { 1=Manual } \\
0=\text { Professional, technical, manager, sales, } \\
\text { clerical, supervisor, not employed, }\end{array}$ \\
\hline Attachment towards EU & How attached do you feel to the EU? & $\begin{array}{l}1=\text { Very attached / Fairly attached } \\
0=\text { Not very attached / Not at all attached }\end{array}$ \\
\hline Support rights inside own country & $\begin{array}{l}\text { Have you ever done one of the following to support the rights of } \\
\text { people/groups in your own country? }\end{array}$ & $\begin{array}{l}1=\text { Yes, at least one } \\
0=\text { No }\end{array}$ \\
\hline Support rights in EU & $\begin{array}{l}\text { Have you ever done one of the following to support the rights of } \\
\text { people/groups in other countries within the EU? }\end{array}$ & $\begin{array}{l}1=\text { Yes, at least one } \\
0=\text { No }\end{array}$ \\
\hline Support rights outside EU & $\begin{array}{l}\text { Have you ever done one of the following to support the rights of } \\
\text { people/groups in countries outside the EU? }\end{array}$ & $\begin{array}{l}1=\text { Yes, at least one } \\
0=\text { No }\end{array}$ \\
\hline
\end{tabular}




\begin{tabular}{|l|l|l|}
\hline Effect of foreigners in home country & Effect on the economy that foreigners come to live here & Scale from 0 (Bad) to 10 (Good) \\
\hline $\begin{array}{l}\text { Would mind having immigrants/ } \\
\text { foreign workers as neighbours }\end{array}$ & $\begin{array}{l}\text { Would you mind having immigrants and foreign workers as } \\
\text { neighbours? }\end{array}$ & $\begin{array}{l}1=\text { Yes } \\
0=\text { No }\end{array}$ \\
\hline Left-right scale & Left and right in politics & Scale from 0 (Left) to 10 (Right) \\
\hline Political knowledge & $\begin{array}{l}\text { Can you tell who the person in this picture is? (Jean Claude } \\
\text { Juncker, current President) }\end{array}$ & $\begin{array}{l}1=\text { Yes } \\
0=\text { No / Don't know }\end{array}$ \\
\hline Political interest & How interested, if at all, would you say you are in politics? & $\begin{array}{l}1=\text { Quite interested / Very interested } \\
0=\text { Not at all interested / Not very interested }\end{array}$ \\
\hline
\end{tabular}

Table A4. Multilevel logistic random intercept model of Brexit preferences in eight European countries

\begin{tabular}{|c|c|c|c|c|c|c|}
\hline Models & $(1)$ & $(2)$ & (3) & (4) & $(5)$ & $(6)$ \\
\hline \multicolumn{7}{|l|}{ Individual level } \\
\hline Age & & $\begin{array}{c}0.054 * * * \\
(0.008)\end{array}$ & $\begin{array}{c}0.053 * * * \\
(0.008)\end{array}$ & $\begin{array}{c}0.041 * * * \\
(0.009)\end{array}$ & $\begin{array}{c}0.041 * * * \\
(0.009)\end{array}$ & $\begin{array}{c}0.041 * * * \\
(0.009)\end{array}$ \\
\hline Age squared & & $\begin{array}{c}-0.001 * * * \\
(0.000)\end{array}$ & $\begin{array}{c}-0.001 * * * \\
(0.000)\end{array}$ & $\begin{array}{c}-0.000 * * * \\
(0.000)\end{array}$ & $\begin{array}{c}-0.000^{* * * *} \\
(0.000)\end{array}$ & $\begin{array}{c}-0.000 * * * \\
(0.000)\end{array}$ \\
\hline Female & & $\begin{array}{c}-0.191 * * * \\
(0.039)\end{array}$ & $\begin{array}{c}-0.152 * * * \\
(0.040)\end{array}$ & $\begin{array}{c}-0.227 * * * \\
(0.045)\end{array}$ & $\begin{array}{c}-0.227 * * * \\
(0.045)\end{array}$ & $\begin{array}{c}-0.227 * * * \\
(0.045)\end{array}$ \\
\hline Lower education & & $\begin{array}{c}0.357 * * * \\
(0.046)\end{array}$ & $\begin{array}{c}0.338 * * * \\
(0.047)\end{array}$ & $\begin{array}{c}0.188^{* * *} * \\
(0.053)\end{array}$ & $\begin{array}{c}0.189 * * * \\
(0.053)\end{array}$ & $\begin{array}{c}0.188 * * * \\
(0.053)\end{array}$ \\
\hline Unemployed & & $\begin{array}{c}0.232 * * * \\
(0.071)\end{array}$ & $\begin{array}{c}0.234 * * * \\
(0.072)\end{array}$ & $\begin{array}{c}0.184 * * \\
(0.080)\end{array}$ & $\begin{array}{c}0.180 * * \\
(0.080)\end{array}$ & $\begin{array}{c}0.183 * * \\
(0.080)\end{array}$ \\
\hline Born in country & & $\begin{array}{c}0.366^{* * * *} \\
(0.075)\end{array}$ & $\begin{array}{c}0.369 * * * \\
(0.076)\end{array}$ & $\begin{array}{c}0.058 \\
(0.084)\end{array}$ & $\begin{array}{c}0.057 \\
(0.084)\end{array}$ & $\begin{array}{c}0.058 \\
(0.084)\end{array}$ \\
\hline Manual occupation & & $\begin{array}{c}0.225 * * * \\
(0.053)\end{array}$ & $\begin{array}{c}0.241 * * * \\
(0.054)\end{array}$ & $\begin{array}{c}0.080 \\
(0.060)\end{array}$ & $\begin{array}{c}0.081 \\
(0.060)\end{array}$ & $\begin{array}{c}0.080 \\
(0.060)\end{array}$ \\
\hline Left-right political scale & & & $\begin{array}{c}0.109 * * * \\
(0.008)\end{array}$ & $\begin{array}{c}0.045^{* * * *} \\
(0.009)\end{array}$ & $\begin{array}{c}0.045^{* * * *} \\
(0.009)\end{array}$ & $\begin{array}{c}0.045^{* * *} \\
(0.009)\end{array}$ \\
\hline Political knowledge & & & $\begin{array}{c}0.064 \\
(0.044)\end{array}$ & $\begin{array}{c}0.158 * * * \\
(0.049)\end{array}$ & $\begin{array}{c}0.154 * * * \\
(0.049)\end{array}$ & $\begin{array}{c}0.157 * * * \\
(0.049)\end{array}$ \\
\hline
\end{tabular}


Political interest

Attachment towards EU

Support rights inside UK

Support rights in EU

Support rights outside EU

Effect of foreigners in economy

Mind having immigrant

neighbours

Country level

GDP growth (\%)

Unemployment rate (\%)

Constant

\begin{tabular}{ll}
-0.036 \\
Constant \\
\hline
\end{tabular}

Standard deviation of random coef.

$-0.636^{* *}$

11865
$-0.062$

$(0.046)$

$\begin{array}{ccc}0.179 * * * & 0.181 * * * & 0.179 * * * \\ (0.052) & (0.052) & (0.052) \\ -1.762 * * * & -1.762 * * * & -1.762 * * * \\ (0.046) & (0.046) & (0.046) \\ 0.114 * * & 0.114 * * & 0.114 * * \\ (0.051) & (0.051) & (0.051) \\ 0.006 & 0.005 & 0.006 \\ (0.057) & (0.057) & (0.057) \\ 0.065 & 0.066 & 0.066 \\ (0.056) & (0.056) & (0.056) \\ -0.133 * * * & -0.133 * * * & -0.133 * * * \\ (0.009) & (0.009) & (0.009) \\ 0.290 * * * & 0.291 * * * & 0.290 * * * \\ (0.052) & (0.053) & (0.053)\end{array}$

$-0.361 * *$

(0.166)

0.013

(0.029)

$-0.277$

(0.388)

(0.366)

$-0.707 * * *$

$0.592 * *$

(0.291)

$(0.255)$

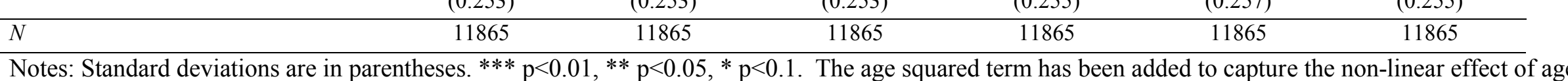

on the dependent variable Brexit. Variables have been introduced sequentially as robustness check. 